\title{
THE ROYAL BOTANIC GARDENS, KEW
}

\author{
CENTENARY OF THE HERBARIUM AND LIBRARY
}

T HE modern history of Kew began in 1841 when the Royal Gardens became a government institution and William Jackson Hooker, professor of botany in the University of Glasgow, was appointed director. There was then neither herbarium nor library at Kew and the new director brought with him his own collections and books. In 1853 Miss E. Bromfield presented to Kew the Herbarium and Library of her late brother, Dr. W. Arnold Bromfield, and these formed the nucleus of the present Herbarium and Library. In 1854 George Bentham gave his valuable collections to be added to the Bromfield Herbarium and Library, and in $\mathbf{1 8 6 6}$ the Government purchased the private collections of Sir W. J. Hooker. The Bentham and Hooker Herbaria, together with new collections that quickly began to be sent to Kew, led to the rapid growth in size and importance of the preserved botanical collections and the essential library. To these early donors or collectors Kew owes a double debt : the richness of the Herbarium in early types and the complete runs of many valuable periodicals in the Library. In addition, the Hookers and Bentham, by the excellence and number of their published researches, made Kew the world centre of botanical, and especially of botanical systematic, studies. The Herbarium now contains some six million 'specimens' and the Library more than fifty thousand volumes.

Since it was in 1853 that the Bromfield collections were presented, it is appropriate that the centenary of the Herbarium and Library at Kew should be celebrated in 1953. To mark the occasion an exhibition of specimens, books, manuscripts, diagrams, photographs, drawings, etc., was arranged in the three wings of the Herbarium and in the Library. Official guests, individual scientists, university students, and members of many scientific societies visited the exhibition during the period May 7-9. The theme of the exhibition was the research carried out at Kew during the past hundred years, and particularly that in connexion with the systematics of plants. About fifty separate but interconnected series of exhibits, some of them extensive, were staged by members of the staff, who ably demonstrated their special subjects.

The early period of Kew, and of the Herbarium and Library in particular, was illustrated by photographs, plans, drawings, and original items of historical interest. The unbroken sequence of administration could be followed through the periods of directors from Sir W. J. Hooker to the present director, Sir E. J. Salisbury, and of keepers from Prof. Daniel Oliver to the present keeper, Dr. W. B. Turrill. It was clearly shown that, in addition to carrying the burden of administration, now greatly increased, both the directors and keepers contributed considerably to botanical knowledge by their own researches.

The work of the Herbarium is divided into departments on a double basis, purely systematic and phytogeographical. The systematic divisions were well illustrated by the work done at Kew on the cryptogams. Collections of Algæ dating from the voyages of H.M.S. Erebus and Terror and of H.M.S. Challenger were on view as well as those used by well-known algologists. The taxonomy of fungi has received much attention at $\mathrm{Kew}$ during the past century, and the collections and work of Cooke, Massee, Wakefield, and others attract many mycologists to study, often for long periods, in the Herbarium. Selections from types of W. J. Hooker to recent additions illustrated the rich material of liverworts and mosses preserved in the Herbarium and now being revised. The pioncer investigations of W. J. Hooker and J. G. Baker on the ferns and fern allies greatly enriched Kew in type specimens. Examples of their matcrials and the results of their researches were contrasted with a fine collection of living plants of twenty-six genera of ferns recently gathered in Ceylon and now being grown at Kew. This was only one of many exhibits showing the facilities existing, and utilized, at Kew for linking together the study of living plants with the examination and comparison of numerous preserved specimens of diverse origins.

There are at Kew specialists for the orchids and grasses, but most of the work carried out on the seed-bearing plants is divided on a geographical basis. Monographic studies have not been neglected; but, partly because of the need for development of what are now Dominions, Colonies, or Protectorates, a major item in the policy at Kew has been, and still is, to prepare Floras of arèas usually with political boundaries. These sometimes coincide closely with phytogeographical divisions, but are sometimes more or less artificial. The practical advantages of having accounts complete to date of publication, with descriptions, keys to determination of taxa, summaries of known range and distribution, etc., for this or that portion of the Commonwealth, needs no emphasis. Their preparation should naturally be a British enterprise and, moreover, involves no competition with either the preparation of floras for other parts of the earth's surface or with that of systematic monographs such as those of the "Pflanzenreich".

In preparing the centenary exhibition, members of the staff had a wealth of material from which to select subjects to illustrate the contributions of their predecessors and themselves to floristic research. A tabulation based on a map of the world listed fortyone Floras prepared entirely or largely at Kew. These ranged from single volumes, as those of Bentham and Hooker "Handbook of the British Flora", or the "Flora Simlensis", to the many volumes of the "Flora of British India" or the "Flora of Tropical Africa". A complete survey of the floristic and phytogeographical interests of past and present members of the Kew staff, and of other botanists who have carried out much of their work at Kew, would occupy much space, and here only a brief account of some of the collections and of work published as a result of investigations conducted at or in connexion with Kew can be given. Since the time of Bentham and Hooker, many members of the Herbarium staff have carried out field studies on the British flora as a recreation, mainly concentrating on a few special families such as those of the orchids, sedges, and grasses or detailed investigations of smaller groups. The Herbarium, in fact, contains valuable special collections of British plants such as 
those of Bromfield, Lightfoot, Borrer, and Watson. It happens that three or four species new to the British flora have quite recently been first recorded from material sent or brought to Kew. Specimens of these were exhibited. The flora of Europe and the Orient (Nearer East) is well represented in the collections, and researches, especially on the plant life of the Balkan Peninsula and Cyprus, have been published in book form and in series of papers. The rich harvest of plants from China garnered by Henry, Wilson and other famous collectors must be consulted by students of plants of the Far East, and its importance is enhanced by the many species introduced into horticulture. The "Index Floræ Sinensis" is based almost entirely on material at Kew. The service of J. D. Hooker to our knowledge of Indian plants must always be acknowledged since it culminated in the classic "Flora of British India". This was followed by the publication of a series of more local floras, many of which were prepared at Kew. The plants of Siam were largely worked out by a former member of the Kew staff, and the "Flora of the Malay Peninsula" is indissolubly linked with Kew.

The greater part of the continent of Africa has been covered botanically by Kew publications, including the "Flora of Tropical Africa", the "Flora Capensis", the "Flora of West Tropical Africa" (now under revision), Hooker and Ball's work on Morocco, and numerous other books and papers. Publication of the "Flora of Tropical East Africa" has recently begun. Exhibits connected with these and other floristic researches consisted of dried specimens, living plants (many illustrating special morphological features or peculiar physiological behaviour), statistical tables, drawings and paintings, methods of collecting, and of printed books and papers.

Bentham's "Flora Australiensis" and J. D. Hooker's Floras of the southern hemisphere together form the foundation of all subsequent studies of the flora of Australasia. Much of the later floristic research has been carried out by Australian and New Zealand botanists at their own institutions; but Kew has always maintained the happiest relations with them and a great interest in their work, and they continually add new specimens to the extensive representation. Samples of the collections recently made in the Montebello Islands were exhibited.

Apart from early researches on the floras of temperate North America and Central America, relatively less work has been done at Kew on American botany than on the plants of other continents. Exceptions to this generalization are the continued investigations concerning the botany of Trinidad and Tobago and British Guiana.

Mention must be made of Kew's contribution to the general classification of flowering plants as exemplified in the "Genera Plantarum", the "Index Kewensis", the new arrangement in "Families of Flowering Plants", and the contribution of members of the staff to the modern International Rules of Plant Nomenclature. Exhibits connected with these were varied and instructive.

'The Kew collection of drawings, paintings, and photographs of plants is the most comprehensive in the world. Fine series illustrative of the work of both Kew artists and of that of others from the fifteenth century to the present day formed a notable feature of the exhibition. Other special exhibits illustrated researches (including cytological) in connexion with the National Dianthus Collection, the methods of preserving plant materials, the organization of herbarium work, the use and preparation of Floras, plant teratology, researches on the genus Utricularia and on Bromus carinatus, the use of genetics in taxonomy, and the introduction of plants to horticulture.

The researches carried out by the Herbarium staff at Kew are mainly taxonomic in the widest sense of this term. Modern taxonomy includes more than describing and naming dried specimens. The close co-operation of the Herbarium staff with that of other departments of the Royal Botanic Gardens, Kew, was evident in the numerous well-chosen examples of living plants from all parts of the earth and all connected with researches carried out by past or present scientists at Kew. Again, the importance to taxonomists of anatomical and physiological characters was emphasized by a large exhibit of apparatus, slides, and accounts of experiments staged from and illustrative of the work of the Jodrell Laboratory. Though the work at Kew is primarily scientific research, problems of immediate economic importance are often closely linked with and sometimes lead to special investigations. Samples of such connected with timber, fibre-, perfume- and oil-producing plants, species yielding drugs, and crops of various kinds were on view with the published results.

In the Library, visitors were able to see many of the valuable books from the libraries of Bromfield, Bentham, and W. J. Hooker, as well as others more recently acquired. Old herbals, manuscripts, diaries, and original drawings were also on view. Books purchased by the Bentham-Moxon trustees add greatly to the usefulness of the Library. A special exhibit showed some of the books written by mombers of the Kew staff and of the periodicals prepared at and, in part, published by Kew : the Kew Bulletin, Icones Plantarum, "Index Kewensis", and (edited at. Kew for the Royal Horticultural Society) the Botanical Magazine and the "Index Londinensis".

\section{SIZE AND SHAPE OF MACROMOLECULES*}

By Prof. H. W. MELVILLE, F.R.S. Chemistry Department, University of Birmingham

POLYMER molecules of natural or synthetic origin can be generally classified as linear, branched or cross-linked. Sometimes these molecules are referred to as one-, two- or three-dimensional. respectively, the reason being that a linear molecule may be varied in length over a very considerable range, from a matter of a few angstroms up to as much as nearly a hundred thousand. Similarly, a two-dimensional molecule if placed on a plane surface may be extended in two directions up to the same kinds of limit. Correspondingly, a three-dimensional molecule may extend, without limit, in three dimensions. In this last-named casc it is true to say that any isolated piece of polymer may represent one giant molecule, though in many actual cases there may be embedded in the three-dimensional array of atoms linear and branched-chain molecules, produced as a result of the synthetic process.

Progress in determining the size, shape and structure of these types has been very uneven, and

* Substance of a Friday Evening Discourse given at the Royal Institution on March 20. 